\title{
Many Lives of Women Rectors at Turkish Universities
}

\author{
Suzan Ustun ${ }^{1}$, Ali Ilker Gümüseli ${ }^{2}$ \\ ${ }^{1}$ Educational Management and Supervision Dept., Social Studies Institute, Okan University, Istanbul, Turkey \\ ${ }^{2}$ Faculty of Education, Okan University, Istanbul, Turkey \\ Correspondence: Suzan Ustun, Educational Management and Supervision Dept., Social Studies Institute, Okan \\ University, Istanbul, Turkey.
}

Received: May 15, 2017

doi:10.11114/jets.v5i8.2424
Accepted: July 3, $2017 \quad$ Online Published: July 21, 2017

URL: https://doi.org/10.11114/jets.v5i8.2424

\begin{abstract}
Women at Turkish Universities do not have the same level of representation as rectors as they have academics at the higher education. It is vital to have women, as one of the genders which comprises the community, at the higher education management as rectors to ensure the gender equality in Turkey. As well as the traditional roles assigned to women in Turkey, the lack of legal arrangements and challenges based on gender discrimination faced by women might be the cause of the women's low representation in the higher education management. This study aims to explicate the experience of being a woman rector through qualitative data gathered from four rectors working at state and foundation universities in Turkey. The low representation of women in higher education management has been identified as a universal problem. It is obvious that woman academics in Turkish universities have low representation at the universities' top management. Following two themes were identified: Perspectives of Women Rectors Regarding Their Roles and Challenges Faced. These themes were revealed through the voices of women rectors in Turkey. Therefore, this study is expected to bring unique insights both for university administrators and policy makers in terms of raising an awareness for the role of women leaders.
\end{abstract}

Keywords: women rectors, higher education management, woman leaders, gender equality, gender discrimination

\section{Introduction}

As a teacher who has been working in the Turkish Education System for eighteen years, I have always found the number of women in the education sector is something that is worth closer analysis. In those years, however, I have realized that this higher number of women in the sector doesn't mean that women in Turkey have the same level of representation in the educational management sector. According to the data given in February 2014 by the Ministry of Education Strategy Development Center only 15.970 (15, 51 \%) out of 103.004 state school managers were women. What stroke me in the related scholarship was that the low representation of women in the educational management sector is a universal phenomenon. Moreover, this low representation also exists in the higher education management. The report on "Women in Higher Education" prepared by UNESCO highlighted the lack of comprehensive and international studies on the place of women in higher education management. The limited national data showed that women's proportion in the higher education institutions' academic and management positions is about $50 \%$. Women's representation is high in low academic titles and middle level management whereas women's representation in high level management is low compared to men. Women's representation at middle level management is about ten to twenty percent, whereas this proportion at the high level management is between zero to ten (UNESCO, 2003).

The authors decided to investigate the ways in which women are represented as rectors in higher education institutions. The authors of this study are actively engaged in higher education; the first author as a $\mathrm{PhD}$ candidate in Educational Leadership and the second author both as a Professor in Educational Leadership and a male Academic Leader in Higher Education Institutions more than three decades. This article presents the findings of a qualitative study conducted with four woman rectors in higher education institutions. First the literature on the low representation of women in higher education is shared. We, then, analyze the narratives of the female rectors to find out how they perceive their roles and the challenges they encounter in their career paths. This study is expected to reveal the narrative stories of female rectors in a way to contribute to the scholarship of higher education leadership as well as providing an interdisciplinary perspective for feminist studies. Moreover, in-depth stories could provide some practical insights for policy-makers and higher education institutions. 


\subsection{The Low Representation of Women in Higher Education Management}

There might be various reasons for the low representation of women in higher education management. The glass ceiling syndrome is defined as the invisible obstacles that prevent qualified people from moving up in their careers. This term was first used in the USA in the 1970s and then has been often used to describe the obstacles that women face in their management careers. Laufer (2002; (She Figures, 2012) uses this term, the glass ceiling syndrome or vertical discrimination, to explain the visible and/or invisible obstacles that stop women taking the decision making positions of the organizations.

The Glass Ceiling Index (GCI) measures the chance of women compared to men reaching higher levels in their career. If the index is " 1 ", it means there is no difference between men and women in promotions. The values above one shows the existence of the glass ceiling. The higher the glass ceiling index means the thicker the glass ceiling; therefore it is difficult for women to reach higher levels in their jobs. According to the statistics released by the European Union in 2012 , the glass ceiling index was not " 1 " or below in any country in 2010. The same report states that the glass ceiling index for Turkey is 1.25 between the years 2004-2010. Despite the fact that Turkey has the best glass ceiling index in higher education in Europe, the glass ceiling is at another level for women academics. It exists at a level where women want to move to the management positions (Women Leaders in Higher Education Workshop Report, 2014).

The glass ceiling which is seen as an obstacle for women's promotion later was described by another term "sticky floor". Maron and Meulders (2008; She Figures, 2012) defines the sticky floor as factors that keep women at the lower levels of organizations Reskin and Padavic (2006; Iverson, 2011) claim that women cannot move up high enough to see the glass ceiling; they are stuck with the low level jobs because of the "sticky floor". Myerson and Fletcher (2000; Iverson, 2011) observes that what hinders women's promotion is not the glass ceiling but the structures of the organizations in which they work.

According to West and Curtis (2006; Martin, 2011) women in higher education face more challenges compared to women in corporate business. Jones (2006), on the other hand, mentions both inner and outer obstacles for women when they move to a management career. These obstacles could be the male oriented routines and structures of jobs in organizations; women's perceptions of themselves as inadequate for management positions and therefore their reluctance to apply for these positions. Women also have to decide which to choose: child care, house care... or the necessities of the work life such as working hours, long meetings or travelling. The concerns that management roles may also require geographical mobility, the traditional roles assigned to women by societies, the lack of role models and mentors in women management can also be considered as other obstacles (Steyn and Parsaloi, 2014).

The report on "Women in Higher Education Management" prepared by UNESCO (2003) points out that the factors which cause the low representation of women in higher education management are the same as the factors that hinder women reaching equal higher education rights. These factors stem from the cultural perceptions of women's role. The first factor stated in a UNESCO report is that a low number of women have-access to higher education. This naturally results in fewer numbers of women in the manager's pool in many countries. The second factor is the discriminative attitudes regarding women's attainment and promotion in some countries. The traditional roles assigned to women, dual responsibilities, partners' or spouses' attitudes, necessary breaks to career development due to pregnancy and childcare responsibilities, men's resistance to women management, the lack of legal arrangements in favor of women and the glass ceiling syndrome are the other factors that cause women's low representation in higher education management (Women in Higher Education Management, 1993).

The research done on the causes of why there are a few women as rectors in universities by Ozkanli and White (2011) in Turkish and Australian universities showed that for women in Turkey, due to the role conflicts affected by cultural factors might be the reason for not volunteering managerial roles. In Australia there are legal arrangements to increase women managers. However, the lack of legal arrangements in favor of women management in Turkey might cause the lower number of women as rectors.

A comparative study done in Turkey and Portugal examined the effect of social gender on academic career development, the differences between the woman and man academics' career development (Ozkanli and Taylor, 2013). It is found out that there are no barriers to women's career development in both countries but women create their own barriers. Women prefer flexible working hours so they can have more time for their household duties as imposed by the society and that is why they are reluctant about managerial roles.

Ozkanli (2010) studied the cultural and structural barriers that high level woman managers in Turkish universities face. This study reached the conclusion that in some Turkish universities the gender discrimination exists; however, even many rectors lack awareness of cultural and structural factors that lead to discriminative perceptions, yet.

Although there are some studies on the challenges such as the traditional roles assigned to women, gender 
discrimination etc. women face in the higher education management, it is usually ignored how women cope with those challenges. There aren't any special studies on challenges of women rectors in Turkey and how they deal with those challenges.

Maya (2012) identified some national, organizational, and individual policies regarding women's participation in higher education management in some European Union countries. She also found out that the best examples about this issue exist in Norway, Sweden, Denmark and Finland; where there are some positive developments in the area of women leadership in higher education management.

Despite the lack of policies regarding women's participation in higher education management, there are some efforts to increase the number of women in higher education management in Turkey. Turkish Universities Leadership Development Program (TULIP) organized the first "Improving and Strengthening Women's Leadership in Higher Education Workshop" (Yuksekogretımde Kadin Liderligini Gelistirme ve Guclendirme Calistayı) in 2012 at Duzce University. It was aimed to encourage woman academics to volunteer for management and leadership roles through this program. This workshop was reorganized in 2013 and the report on improving and strentgtening women leadership and mentor program in higher education was published in the same year. The similar workshops were organized in 2014 and 2015 with the help of Ministry of Family and Social Policies and Duzce University. There was also a panel discussion on "Women Leadership in Higher Education: Today and Future" on March 12, 2015 at Duzce University; where the solutions to and suggestions for the barriers to the woman leadership were discussed.

\section{Method}

In this study, a qualitative research was conducted to hear the female rectors' voices regarding their role in Turkish universities. The narratives derived from the participants' genuine feelings and experiences made the findings of the study more valuable. Qualitative research has some possible limitations and weaknesses in data collection and analysis process. Authors tried to decrease these possible problems by carrying out one-on-one unstructured interviews in which participants were asked open-ended questions so that female academic leaders could voice their own experiences, perspectives, feelings and perceptions.

Each interview lasted 60 to 90 minutes. The first author conducted all the interviews as well as transcribing word by word.

During the analysis process, on the other hand, authors conducted an external audit. We worked with five field experts who are outside this study and benefited from their perspectives while identifying the codes and emerging themes. Each expert was sent the transcriptions and asked to identify codes and themes. Then the group came together to compare and contrast the results. The authors had six meetings, each lasted 90 minutes, with the field experts to finalize the emerging themes.

The content analysis was preferred to analyze the data gathered during this study. By using Yildirim and Simsek (2013) as a reference for the content analysis; first the data was coded. Next, themes were identified. As the third step, codes and themes were organized and finally findings were defined and interpreted by using the voices of women rectors.

\subsection{Participants}

Participants in this study were four female leaders from foundation and state universities in Turkey. There are two types of universities in Turkey. In state universities, the rector on duty invites the academics to choose six candidates to be the new rector. Higher Education Council chooses three candidates from the list sent from the university and presents its own list to the President. The President chooses the one out of three candidates as the Rector. In Foundation Universities, The Board of Trustees chooses one rector and presents it to the Higher Education Council for approval. After the Council's approval, the rector is assigned to his/her work (Academic Organization Regulations for Universities, 2015).

\subsection{Sampling Procedures}

For the aim of this study, snowball sampling as a form of purposeful sampling was preferred in order to reach the best people to study as Creswell (2005) suggested. Each participant rector was given a pseudonym to protect their identity.

\section{Emerging Themes}

Two themes were identified as a result of the content analysis of the data gathered. These themes and their sub-themes are presented in Table 1. 
Table 1. Themes and sub-themes of being women rectors at Turkish Universities

\begin{tabular}{l|l}
\hline Themes & Sub-themes \\
\hline Theme 1. Perspectives of Women Rectors Regarding Their Roles & $\bullet$ Minority \\
& $\bullet$ Contentious \\
& $\bullet$ Mentor \\
\hline Theme 2. Challenges Faced & $\bullet$ Glass ceiling \\
& $\bullet$ Resistance \\
\hline
\end{tabular}

3.1 Theme 1. Perspectives of Women Rectors Regarding Their Roles

While defining their roles, women rectors mentioned being few in numbers, contentious and mentor as well as being self-confident. Being a woman rector at a Turkish university means being an academic as well as a manager in a male dominated area. In addition to this dual role, women rectors are expected to fulfill traditional roles assigned to them by the society; therefore it requires to be a contentious. While voicing the prejudices, they also aim to set right role-models for future generations. In other words, they try to mentor young women in universities.

The first theme covers the following sub-themes: Minority, contentious, mentor, and self-confident.

\subsubsection{Minority}

All the women rectors interviewed during this study considered themselves as a minority because of the low representation of women rectors in Turkish universities. According to the report published in June 2014 by the Turkish Republic Ministry of Family and Social Politics the Status of Women Department, the percentage of woman professors, associate professors, assistant professors, instructors, researchers is $41 \%$. What is interesting and worth studying here is that the percentage of women rectors is meaningfully below the percentage of woman academics. The rectors interviewed mentioned this low representation of women at higher education management as $22 \%$ and at rector position as $7 \%$.

One of the women rectors working at a foundation university underlined the situation in Turkey in comparison with the other countries. Her words revealed the ways in which the number of women in academic positions is high whereas the number of women rectors is low.

We are very good in the number of woman academics. This number is low for woman professors however, it is well above the numbers in Europe and the USA. The number of woman deans is low. The number of women rectors is low, too. It is either 13 or 11. Not more than this. What is our population? How many people are you talking about? This itself is an interesting topic... (Rector Tracey, Foundation University, March, 2015)

Another woman rector's words explain the situation in numbers as follows.

There are only 12 women rectors in 185 universities. We are such a small group. (Rector Sally, Foundation University, April, 2015)

As could be seen from the above mentioned excerpts, all the women rectors highlighted the small proportion of women represented in higher academic leadership positions. This finding aligns with the sub-theme of being contentious which is given in the remaining section of the article.

\subsubsection{Contentious}

The constraints experienced as a woman rector has been mentioned by the participants so far. However, all the participants noted that the role as a rector requires many interrelated challenges itself. It was revealed by the rectors interviewed that this job either done by a man or woman is a difficult job to do. They emphasized that their responsibility is very much as a rector. They also declared that the biggest change in their lives is the excessive stress due to their responsibilities. Being a rector is a managerial job. When this combines with the roles such as motherhood and housekeeping that are assigned to women by the society, women rectors have to struggle a lot. Women rectors, in a male dominated area, also have to struggle more than male rectors to be considered as a manager by others.

Of course this higher manager title brings a lot of changes to one's life. Responsibility for 24 hours 7 days. A day sometimes is not enough. (Rector Sally, Foundation University, April, 2015)

I am really busy but I have always been very busy. I am older now. There aren't many changes in my life but stress. Only stress. It has increased a lot. It is not an easy job to be a manager. (Rector Tracey, Foundation University, March, 2015) 
Leadership and management require full time working and spending too much energy while sacrificing your private and social life. Sometimes, as a woman you need to work more than men to overcome the prejudices against woman managers. (Rector Jane, State University, May, 2015)

It was revealed from the experiences that all the women rectors struggle to keep a balance in their lives after taking this high stakes position. Their words echoed each other in a way that being a rector requires a full commitment and readiness to compensate from their lives. Their voices also showed that they have to be skillful to manage their multiple roles and responsibilities. Hacifazlioglu (2010), in her study with women academic leaders also mentions the very same issue that maintaining work-life balance is a challenge for women leaders in their career journey.

\subsubsection{Mentor}

The conscious effort of mentoring due to the low representation of their gender in higher education management is the most emphasized topic by the women rectors while defining their roles. All the women rectors considered being a role model as an important duty. Women rectors believe that mentoring woman academics is necessary to increase the number of women in higher education management and despite all the difficulties, this job can be successfully done by women, too.

Following words were heard almost in all the participants' voices:

Women rectors are few about $7 \%$ and they have an important responsibility to be a role model. For example, in the USA, the percentage of women rectors is $25 \%$. In Turkey, it is $7 \%$. This means our biggest responsibility is to be a role model. It is not just for higher education management though. It is important for women in higher management positions to be role models in other sectors, too. (Rector Sally, Foundation University, April, 2015)

It is necessary for woman managers to pull young women to management. It is necessary to give them initiatives. It is necessary not to forget their existence. I am talking about being a pull force. There is enough push force. The pull force is necessary. It is important to give them a hand, to mentor them. (Rector Tracey, Foundation University, March, 2015)

I am a woman leader and a manager who always believe the importance of being a mentor. I also believe the importance of peer mentoring. However, the most important thing here is to train women for managerial roles at earlier stages so that they can be assigned to higher roles later. We are lucky because our pipeline is full. The percentage of woman professors is 28\%. (Rector Wendy, State University, June, 2015)

The effect of mentors on the progress of women in their career path is also supported by Hacifazlioglu (2010). Women need right role models or mentors who would guide them through their journey to the managerial positions.

\subsubsection{Self-confident}

The other theme that describes the role of rectors in the study is that they all have high self-confidence. High self-confidence is an important personality trait while rectors describe how they cope with challenges they face. Women rectors who have high self-confidence along with strong communication skills display decisive and strong portraits. The women rectors also show that they can cope with personal, societal and structural barriers with the help of their self-confidence.

A smart institution would benefit from women's energy. I am completely sure that there is a difference between the energy of a man and a woman. There is a difference between woman's and man's diligence. There is a difference between the attention of man's and woman's. Therefore, although all the weak points that exist, women have all the pros. So, it is foolishness not to benefit from this. A smart institution would want to benefit from this because it is a good thing. (Rector Tracey, Foundation University, March, 2015)

The confidence and comfort of a well- deserved position. Sincerity and assurance. As a woman, you have to take initiatives courageously. (Rector Wendy, State University, June, 2015)

Their reflections of their role as a woman rector imply the challenges and road blocks encountered in their journey as a leader and a woman. In line with this finding the second theme was based on the challenges encountered by the participants.

\subsection{Theme 2. Challenges Faced}

Having a managerial job is naturally challenging; however women face different challenges than men when they are assigned to or when they apply for managerial positions. These challenges identified in this study are namely the glass ceiling syndrome, resistance and the men's club.

\subsubsection{Glass Ceiling}

The glass ceiling syndrome; in this study too, is a theme which describes one of the challenges of the women rectors. Turkey's glass ceiling index in European Higher Education is 1.25. This indicates that there aren't any problems for 
women to get promoted; however the glass ceiling is at a different height where woman academics want to be rectors. The women rectors of state universities stated this explicitly; therefore it can be thought that the glass ceiling syndrome is more intensive in state universities.

One of the rectors from a state university used the metaphor of a room that described the isolation of women in leadership roles when the majority of the population was male.

It is a crowded room. There is a woman in the manager position. It is indeed not easy. The glass ceiling syndrome is very important and it has to be broken. You get until there and then you are stuck. You cannot get through that ceiling. This is a serious problem. (Rector Wendy, State University, June, 2015)

The committees who choose the managers are composed of men, the evaluation process is controlled by male dominated teams. This, of course, is advantageous for male candidates. Gender discrimination is hidden; even the women who are exposed to discrimination may not be aware of the situation... (Rector Jane, State University, May, 2015)

Glass ceiling syndrome is not the only challenge faced by women rectors; but it is explicitly or implicitly experienced by most of them. Women rectors interviewed for this study though agreed on the fact that the glass ceiling is something that needs to be broken.

\subsubsection{Resistance}

Another challenge the women rectors face before they are assigned to their jobs or while in charge is the resistance. However, there seems to be a difference between the state and the foundation universities regarding the resistance. In state universities, there is a candidacy period during which women feel the resistance more. In state universities again, men academics' resistance to women rectors tend to continue even when the women rectors are in charge.

I often have difficulties. Although we are among educated people here, even though they try not to make it obvious, from very close friends to people you don't know well can be disturbed about a woman rector. They see this as a manhood issue. Unfortunately, it is the same in departments. Universities are the last places to have this problem. They are okay with woman academics; but if that woman becomes a rector and manages them, it is something else. I know that there is an important group of people who aren't very pleased with me as a rector since I I am a woman. They politely try to hide their feelings but as a woman I feel it. First of all, it takes some time to get used to that scenery. Think of a senate meeting. It is crowded. There is a woman sitting in the manager's chair. Yes, that is not easy to accept for some. (Rector Wendy, State University, June, 2015)

There is a different election process in foundation universities. In foundation universities, women rectors do not think that they face resistance because of their gender. However, even they do not claim that there is no resistance.

I have been always asked if I have ever been kept down. As you see, I am a rector as a woman so I haven't been prevented. Now, there is elections. There are many criteria there and being a woman is not one of them. I do not think that women are hindered except from by some really weird environments. (Rector Tracey, Foundation University, March, 2015)

Whether they are in state or foundation universities, women rectors feel resistance at different levels. This resistance may stem from the position itself; male rectors may experience some resistance during their management but it may also stem from the gender that female leaders have to cope with a different kind of resistance just because of being a woman.

\subsubsection{Men's Club}

The notion of men's club is a common difficulty mentioned by all the women rectors in this study. It is obvious from their voices that higher education management in Turkey is male dominated. The number of male rectors in Turkish universities supports this argument as well. While talking about the current context in higher education in Turkey, participants supported their views by giving examples from the Turkish Higher Education Council. Almost all of them asserted the fact that even among the academics, the number of men are more than women. Turkish Higher Education Council has nineteen members; and only two of the members are women. This council has had seven presidents until 2015 and they have been all men. All this data reinforces the notion of what women rectors name as men's club. Women who have to or prefer to stay out of this unique social environment of men may be disadvantaged because they do not have access to information shared in those settings. Women rectors are also aware that these social settings also strengthen the men's cooperation.

There is a thing like "men's club". I have never experienced any arrogances anywhere I worked. I have tried to be part of everything socially. If there is a dinner, I join in. This may not be the case for every woman. But there are some small communities I can never be in as a woman; I cannot be in them and I do not prefer it either. There usually business talks take place. This has nothing to do with the university. I mean men have a special area to socialize outside work. You 
cannot smoke a cigar with eight men. You can actually; but this cannot be your routine. Because it wouldn't be considered normal. (Rector Tracey, Foundation University, March, 2015)

I believe that our community, daily routines and hours of the day are kind of designed to make men's promotion more possible. They talk and often come together. Men have the culture and the skill of lobbying, whereas women lack this skill. For instance, if a man want a position, he can easily communicate it. They easily communicate with each other and work behind the scenes. (Rector Jane, State University, May, 2015)

Men have an informal communication webs which I name as "bro webs. When opportunities arise, they let each other know and they support each other. Most of the decisions are made at dinners, backgammon, chess or golf tournaments, at men's clubs through interactions and conversations. We, women, have difficulties because we cannot be part of those social settings. (Rector Wendy, State University, June, 2015)

Apparently, there is a need for "sisters' club" for women. Although women leaders implied the need of some kind of support mechanism that could be created among women, they were also hesitant to be a part of such a group due to gender-biased constraints. Therefore, their words underlined the importance of trust and sincerity that should be established in the networking communities. As suggested in Hacifazlioglu's (2010) study, women leaders might use communities of practice to strengthen their collaboration with other female leaders.

\section{Discussion}

As highlighted by one of the participants;

Under normal circumstances, it is difficult to be a woman in Turkey. Plus, it is difficult to be an academic. You will be both an academic and a woman; and on top of these, you will be a manager... (Rector Tracey, Foundation University, March, 2015)

It can be said that women have to fight in many areas until they reach higher education management as rectors. As a woman, they need to make arrangements in their personal lives as a spouse and/ or mom. As an academic, they also have to fulfill their responsibilities along with their traditional woman roles assigned. Management can be considered as a difficult job for both genders; however with their other responsibilities it can be thought that women have to have a contentious personality to be equally successful. This finding is also supported by Hacifazlioglu's (2010) study's findings in which she found that academic leaders in higher education make an effort to balance their personal and professional lives. Woman academic leaders define their multiple roles and responsibilities in both their personal and professional lives as real but manageable challenges. This also can be another situation that samples women rectors' contentious personality. Women rectors' self-confidence is also important in male dominated higher education management. The traits such being contentious, having high self-confidence and carrying the responsibility to be a mentor can be evaluated without taking gender into consideration since men rectors may also have these traits. However, what the figures clearly reveal about the number of women rectors in Turkey should take the gender issue into account. It leaves no doubt that women rectors are minorities due to their gender.

Likewise, the second theme identified should be analyzed with the gender focus in mind since it describes the challenges women rectors face. Both state and foundation universities' women rectors interviewed mention the men's club which symbolizes men's cooperation among themselves. In these social settings special to men, they can talk about business, make decisions or continue lobbying. This situation could set certain challenges for women during the candidacy period and while they are in managerial positions.

The glass ceiling syndrome which is seen as one of the most important barriers to woman management is another challenge for women rectors. Although Turkey's Glass Ceiling İndex is 1, 25; women may experience this syndrome when they become a candidate for managerial positions. This could be seen one of the factors that cause low representation of women in higher education management. Although the index seems favorable in Turkey, as Maron and Meulders (2008) describe Turkish female leaders may be experiencing "sticky floor" syndrome more intensely than the glass ceiling syndrome.

Resistance, on the other hand, is another challenge faced more by state universities' rectors. While foundation universities' women rectors do not mention resistance as a challenge for themselves, they also point out that circumstances may differ in state universities. The structure of state universities, candidacy processes, and the way they are assigned as rectors are different from foundation universities. Therefore, these differences may be the reasons why women rectors in state universities feel more resistance to their existence.

According to Maya (2012), the lack of regulations regarding gender equality in higher education management is the cause of fewer women in higher management positions at universities. Due to the gender equality policies in European Union countries, some positive developments for woman management have taken place. Sweden is one of the countries that have undertaken some regulations on gender equality in higher education since the beginning of 1970s. The policy 
of gender mix is the most important cause of the increasing number of women in higher education management in Sweden. With the help of the gender mix policy in Sweden, the percentage of woman vice-chancellor increased from $14 \%$ in 1990 to $43 \%$ in 2010 (Peterson, 2011). In Turkey, the number of woman academics is higher than the ones in Europe; therefore the legal arrangements may affect the number of women in higher education management in a positive manner.

It is important that woman academics experience the managerial roles at the early stages of their professional career so they may have their places in the higher education management. The women rectors who emphasized the importance of talent hunting and mentoring see leadership training as an important effort to increase the number of women in the management pool.

This study was carried out with four women rectors, two from state and the other two from foundation universities. During the period of this study, the number of women rectors in Turkey was twelve. The data, the analysis and the findings of the study are limited to the personal views, experiences and perceptions of the four women rectors in the study group. It is necessary to reach all the women rectors in Turkey to make generalizations about the experience of being a woman rector in Turkey.

It would help if further studies could be carried out on women management, barriers to and challenges for women managers. A study on women who tried to be rectors but somehow couldn't achieve this in Turkey would make contributions to the literature about the place of woman in higher education management in Turkey. This kind of study would identify the barriers that women face in their career journey. Moreover, a different study that would focus on the issue of women management from the point of male may add new perspectives to the topic of women in higher education management in Turkey.

Everyone should fulfill their responsibilities to create a better future in which gender equality is well-established and so there will be no need to make legal arrangements to ensure women's rights. It is just one of the important steps to be taken to make gender equality possible in higher education management. Each and every woman, whether a student or an academic, in Turkish universities needs to know successful women in higher management positions better so that they can be inspired by them. As Brown and İrby (2005) state it would be possible to have more women in management if the community is informed well about woman leadership, how women get these positions and how they become successful (Grogan \& Shakeshaft, 2011).

This study aimed to know the women rectors and their career stories better. It is also aimed to hear the women rectors' voices; to show the role models for young women who pursue career opportunities in management and finally to move the higher education management beyond gender.

\section{References}

Academic Organization Regulations for Universities. The Official Gazette: 18.02.1982, Volume: 17609. www. yok.gov.tr. Accessed 23 April 2015.

Creswell, J. W. (2005). Educational Research: Planning, Conducting, and Evaluating Quantitative and Qualitative Research. Addison Wesley.

Grogan, M., \& Shakeshaft, C. (2011). Women and Educational Leadership. $1^{\text {st }}$ Edition. San Francisco, USA: Jossey Bass A Willey Imprint.

Hacifazlioglu, O. (2010). Balance in Academic Leadership: Voices of Women from Turkey and the USA. Perspectives in Education, 28(2), 51-62.

Hacifazlioglu, O. (2010). Entry and Transition to Academic Leadership: Experiences of Women Leaders from Turkey and the U.S. Educational Sciences: Theory and Practice, 10(4), 2221-2273.

Improving and Strengthening Women Leadership in Higher Education Workshop Report, (2012). Duzce University, Turkey, 29 November 2012.

Improving and Strengthening Women Leadership in Higher Education Training and Mentor Program Report, (2013). Duzce University, Turkey, 26-27 April 2013.

Iverson, V. S. Glass Ceilings and Sticky Floors: Women and Advancement in Higher Education. Women as Leaders in Education Succeeding despite Inequity, Discrimination, and Other Challenges Volume 1: Women's Leadership in Higher Education. California, USA: Praeger an Imprint of ABC-CLIO, LLC, 2011, 79- 105.

Martin, L. J. Women as Leaders in Education Succeeding despite Inequity, Discrimination, and Other Challenges Volume 1: Women's Leadership in Higher Education. California, USA: Praeger An Imprint of ABC-CLIO, LLC, 2011, xiv. 
Maya, I. C. (2012). Women's Participation in Higher Education Management: Policies and Strategies of Some EU Countries and Suggestions for Turkey. Journal of Kirsehir Education Faculty (KEFAD), 13(3), 207-222.

Ozkanli, O. (2010). Cultural and Structural Barriers that Women in High Level Management in Turkish Universities Face. Mulkiye, 34(268), 267-281.

Peterson, H. (2011). The Gender Mix Policy-Addressing Gender Inequality in Higher Education Management. Journal of Higher Education Policy and Management, 33(6), 619-628.

She Figures 2012 Gender in Research and Innovation. (2012). European Commission Brussels, 2012.

Steyn, G. M., \& Parsaloi, M. V. (2014). Moving Towards Gender Equality: The Case of Female Head Teachers in Kenya. Gender and Behavior, 12(1), 5980-5993.

Taylor, M. L. M., \& Ozkanli, O. (2013). Gender and Academic Careers in Portuguese and Turkish Higher Education Institutions. Education and Science, 38(169), 346-356.

White, K., \& Ozkanli, O. (2011). A Comparative Study of Perceptions of Gender and Leadership in Australian and Turkish Universities. Journal of Higher Education Policy and Management, 33(1), 3-16.

Women in Higher Education Management. (2003). Paris: UNESCO.

Women in Turkey. (2014). Turkish Republic Ministry of Family and Social Policies Status of Women Management, Turkey.

Women Leaders in Higher Education Workshop Report, (2014). Duzce University, Turkey, 22-24 October 2014.

Women Leadership in Higher Education: Today and Future Panel Report,. (2015). Duzce University, Turkey, 12 March 2015.

Yildirim, A., \& Simsek, H. (2013). Qualitative Research Methods in Social Studies. ${ }^{\text {th }}$ Edition. Ankara: Seckin Publishing.

\section{Copyrights}

Copyright for this article is retained by the author(s), with first publication rights granted to the journal.

This is an open-access article distributed under the terms and conditions of the Creative Commons Attribution license which permits unrestricted use, distribution, and reproduction in any medium, provided the original work is properly cited. 